\title{
Laterality: Immunological Differences Between Right-Sided and Left-Sided Colon Cancer
}

\author{
Seong Kyu Baek \\ Department of Surgery, Keimyung University Dongsan Hospital, Keimyung University School of Medicine, Daegu, Korea
}

\section{See Articles on Page 342-346}

In 1990, Bufill [1] was the first to describe colorectal cancer (CRC) based on its anatomical site of occurrence. Right-sided colon cancer (RCC) is derived from the embryologic midgut, including the proximal two-thirds of the transverse colon, the ascending colon, and the cecum. Left-sided colon cancer (LCC) arises from the embryologic hindgut, including the distal third of the transverse colon, the splenic flexure, the descending colon, the sigmoid colon, and the rectum [2].

In recent years, with increasing knowledge of the genetic and molecular mechanisms of carcinogenesis, CRC is no longer considered a unique disease. Currently, accumulating evidence indicates that CRC exhibits differences in incidence, clinical characteristics, genetic and molecular characteristics, and outcomes depending on the location of the tumor [2]. Patients with RCC tend to be older, female, and have larger, poorly differentiated tumors at more advanced stages compared to those with LCC [3-5]. RCC is associated with frequent metastasis to the peritoneum, while a great proportion of LCC metastasizes to the lung and liver instead [6].

There are underlying gene expression differences between RCC and LCC. Chromosomal instability, which is characterized by mutational activation of the oncogene KRAS and loss of the tumor suppressor genes APC, SMAD4, and TP53, occurs more often in LCC than in RCC [7]. However, RCC has been shown to be associated with $B R A F$ mutations, $\mathrm{CpG}$ island hypermethylation, and

Correspondence to: Seong Kyu Baek, M.D.

Department of Surgery, Keimyung University Dongsan Hospital, Keimyung University School of Medicine, 1035 Dalgubeol-daero, Dalseo-gu, Daegu 42601, Korea

Tel: +82-53-258-7876, Fax: +82-53-258-4710

E-mail:sgbeak@dsmc.or.kr

ORCID code: https://orcid.org/0000-0001-6427-8675

(C) 2019 The Korean Society of Coloproctology

This is an open-access article distributed under the terms of the Creative Commons Attribution NonCommercial License (http://creativecommons.org/licenses/by-nc/4.0) which permits unrestricted noncommercial use, distribution, and reproduction in any medium, provided the original work is properly cited. microsatellite instability $[6,8]$. The international CRC subtyping consortium has defined four molecular subtypes of CRC: consensus molecular subtypes (CMS) 1 to CMS4, each of which has a characteristic molecular background [9]. RCC predominantly includes CMS1, which is characterized by microsatellite instability (MSI) and strong immune activation, while LCC is mostly characterized by CMS2, which is canonical [10].

Although differences in clinical, chromosomal, and molecular characteristics have been reported between RCC and LCC, it is clear that the outcome of CRC is not solely dependent on tumor characteristics but is also related to the quality of the host immune response. There are distinct differences in the mucosal immunology of the right and left sides of the colon. Paski et al. [11] demonstrated that in the healthy adult colorectum, there is significantly increased immune activity in the cecum compared to the rectum. Kirby et al. [12] reported that intraepithelial T cells are more abundant in the proximal colon than in the distal colorectum.

The immune response is influenced by the tumor's genetic structure and the gut microbiota. The gut microbiota population increases with a positive gradient from the proximal colon to the distal colorectum [13]. This difference induces changes in the intestinal epithelial cells and the composition of the immune cell population. Mucosal immunologic differences between the right and left sides of the colon could be explained by the differences in the gut microbiota, which is believed to play an important role in the development of CRC. In the context of CRC, the gut microbiota population also differs in RCC and LCC both quantitatively and qualitatively [14].

The underlying immunological differences may explain the characteristic differences in pathogenesis and the outcomes of RCC and LCC. Kwak and Ju [15] analyzed the difference in immune cell populations in patients with RCC and LCC. Peripheral blood from patients with RCC contained fewer mucosal-associated invariant T (MAIT) $(0.87 \%$ on the right side vs. $1.74 \%$ on the left side, $\mathrm{P}=0.028)$ and gamma delta $\mathrm{T}(\gamma \delta \mathrm{T})$ cells $(1.10 \%$ on the right side vs. $3.05 \%$ on the left side, $\mathrm{P}=0.002)$. RCC had more MAIT cells than LCC ( $1.71 \%$ vs. $1.00 \%$, respectively).

There is a variation in the composition of immune cells, which includes innate lymphoid cells, $\gamma \delta \mathrm{T}$ cells, MAIT cells, natural killer 
T cells, and natural killer cells, within different sites of the colon under different physiological and pathological conditions. MAIT cells are innate-like $\mathrm{T}$ cells that are involved in antibacterial immunity. However, their role and distribution within the large intestine have not been fully determined. They are more likely to be activated in the epithelium of the cecum than in other regions of the colon or in the blood [16]. Sundstrom et al. [17] reported that MAIT cells significantly accumulated in colon cancer tissues. The proportion of circulating MAIT cells was significantly reduced, while that of tumor-infiltrating MAIT cells increased in patients with advanced CRC [18]. The role of MAIT cells in colon cancers has not yet been characterized, but MAIT cells may participate in the immune response in CRC. Zabijak et al. [19] correlated the increase in tumor-infiltrating MAIT cells with poor survival in patients with CRC. Several studies have shown that the presence and density of tumor-infiltrating lymphocytes (TILs) within colorectal tumors is associated with a better overall prognosis [20], and highdensity TILs are more frequently noted in specimens with RCC than in those with LCC [21].

Overall, the existing literature shows significant heterogeneity regarding the immunological composition of the tumor microenvironment of RCC and LCC. However, it is clear that close relationships exist among colon cancer laterality, immune activity, response to treatment, and prognosis. Additional research will be required to define the host immune response and tumor biology more clearly with regard to colon cancer laterality.

\section{CONFLICT OF INTEREST}

No potential conflicts of interest relevant to this article were reported.

\section{REFERENCES}

1. Bufill JA. Colorectal cancer: evidence for distinct genetic categories based on proximal or distal tumor location. Ann Intern Med 1990;113:779-88.

2. Stintzing S, Tejpar S, Gibbs P, Thiebach L, Lenz HJ. Understanding the role of primary tumour localisation in colorectal cancer treatment and outcomes. Eur J Cancer 2017;84:69-80.

3. Nawa T, Kato J, Kawamoto H, Okada H, Yamamoto H, Kohno H, et al. Differences between right- and left-sided colon cancer in patient characteristics, cancer morphology and histology. J Gastroenterol Hepatol 2008;23:418-23.

4. Sinicrope FA, Shi Q, Smyrk TC, Thibodeau SN, Dienstmann R, Guinney J, et al. Molecular markers identify subtypes of stage III colon cancer associated with patient outcomes. Gastroenterology 2015;148:88-99.

5. Weiss JM, Pfau PR, O'Connor ES, King J, LoConte N, Kennedy G, et al. Mortality by stage for right- versus left-sided colon cancer: analysis of surveillance, epidemiology, and end results--Medicare data. J Clin Oncol 2011;29:4401-9.
6. Missiaglia E, Jacobs B, D’Ario G, Di Narzo AF, Soneson C, Budinska E, et al. Distal and proximal colon cancers differ in terms of molecular, pathological, and clinical features. Ann Oncol 2014;25: 1995-2001.

7. Rowan A, Halford S, Gaasenbeek M, Kemp Z, Sieber O, Volikos E, et al. Refining molecular analysis in the pathways of colorectal carcinogenesis. Clin Gastroenterol Hepatol 2005;3:1115-23.

8. Yamauchi M, Morikawa T, Kuchiba A, Imamura Y, Qian ZR, Nishihara R, et al. Assessment of colorectal cancer molecular features along bowel subsites challenges the conception of distinct dichotomy of proximal versus distal colorectum. Gut 2012;61:84754.

9. Guinney J, Dienstmann R, Wang X, de Reynies A, Schlicker A, Soneson C, et al. The consensus molecular subtypes of colorectal cancer. Nat Med 2015;21:1350-6.

10. Lee MS, Advani SM, Morris J, Jiang ZQ, Manyam GC, Menter D, et al. Association of primary $\left(1^{\circ}\right)$ site and molecular features with progression-free survival (PFS) and overall survival (OS) of metastatic colorectal cancer (mCRC) after anti-epidermal growth factor receptor (aEGFR) therapy. J Clin Oncol 2016;34(15 Suppl): 3506.

11. Paski SC, Wightman R, Robert ME, Bernstein CN. The importance of recognizing increased cecal inflammation in health and avoiding the misdiagnosis of nonspecific colitis. Am J Gastroenterol 2007;102:2294-9.

12. Kirby JA, Bone M, Robertson H, Hudson M, Jones DE. The number of intraepithelial $\mathrm{T}$ cells decreases from ascending colon to rectum. J Clin Pathol 2003;56:158.

13. Macfarlane GT, Macfarlane LE. Acquisition, evolution and maintenance of the normal gut microbiota. Dig Dis 2009;27(Suppl 1): 90-8.

14. Lyra A, Forssten S, Rolny P, Wettergren Y, Lahtinen SJ, Salli K, et al. Comparison of bacterial quantities in left and right Colon biopsies and faeces. World J Gastroenterol 2012;18:4404-11.

15. Kwak HD, Ju JK. Immunological differences between right-sided and left-sided colorectal cancers: a comparison of embryologic midgut and hindgut. Ann Coloproctol 2019;35:342-6.

16. Hama I, Tominaga K, Yamagiwa S, Setsu T, Kimura N, Kamimura $\mathrm{H}$, et al. Different distribution of mucosal-associated invariant $\mathrm{T}$ cells within the human cecum and colon. Cent Eur J Immunol 2019;44:75-83.

17. Sundstrom P, Ahlmanner F, Akeus P, Sundquist M, Alsen S, Yrlid $\mathrm{U}$, et al. Human mucosa-associated invariant $\mathrm{T}$ cells accumulate in colon adenocarcinomas but produce reduced amounts of IFNgamma. J Immunol 2015;195:3472-81.

18. Ling L, Lin Y, Zheng W, Hong S, Tang X, Zhao P, et al. Circulating and tumor-infiltrating mucosal associated invariant T (MAIT) cells in colorectal cancer patients. Sci Rep 2016;6:20358.

19. Zabijak L, Attencourt C, Guignant C, Chatelain D, Marcelo P, Marolleau JP, et al. Increased tumor infiltration by mucosal-associated invariant $\mathrm{T}$ cells correlates with poor survival in colorectal cancer patients. Cancer Immunol Immunother 2015;64:1601-8. 
20. Lee GH, Malietzis G, Askari A, Bernardo D, Al-Hassi HO, Clark SK. Is right-sided colon cancer different to left-sided colorectal cancer? - a systematic review. Eur J Surg Oncol 2015;41:300-8.
21. Merlano MC, Granetto C, Fea E, Ricci V, Garrone O. Heterogeneity of colon cancer: from bench to bedside. ESMO Open 2017;2: e000218. 